\title{
Pengaruh Partisipasi Anggaran terhadap Kinerja
} Karyawan dengan Budaya Organisasi dan Kepuasan Kerja Sebagai Variabel Intervening, Bank Rakyat Indonesia Kantor Cabang Bandar Lampung ( The Influence of budget participation to employee performance with organizational culture and worksatis faction-based as intervening variable in Bank Rakyat Indonesia KC. Bandar Lampung)

Tri Utari ${ }^{1 *}$, Yuliansyah ${ }^{2}$, Pigo Nauli ${ }^{3}$

Universitas Lampung ${ }^{1,2,3}$

triutari254@gmail.com $^{l^{*}}$,yuliansyah@feb.unila.ac.id ${ }^{2}$,pigonauli@gmail.com $^{3}$

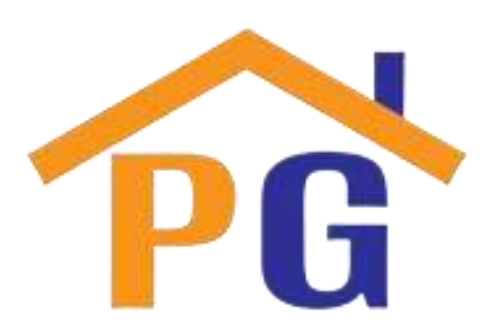

Riwayat Artikel

Diterima pada 12 April 2021

Revisi 1 pada 13 April 2021

Revisi 2 pada 19 Juli 2021

Revisi 3 pada 2 Agustus 2021

Revisi 4 pada 27 September 2021

Revisi 5 pada 8 Oktober 2021

Disetujui pada 19 Oktober 2021

\begin{abstract}
Purpose: The aim of this study is to examine the influence of budget participation to employee performance through organizational culture and work-satisfaction-based.

Research methodology: The influence of budget participation on employee performance with organizational culture and job satisfaction as an intervening variable was carried out using descriptive analysis methods, with data collection applications using a questionnaire.
\end{abstract}

Results: Budget participation has a direct effect on employee performance. The higherthe level of employee participation in the budget preparation process, the better the employee's performance.

Limitations: The sample of this study was only 80 employees at the Bank Rakyat Indonesia, Bandar Lampung Branch, due to time constraints and the Covid-19 pandemic.

Contribution: This research is useful for companies to see whether budget participation affects employee performance.

Keywords: Budgeting participation, Employee performance, Organizational culture, and Work-satisfaction-based.

How to cite: Utari, T., Yuliansyah, Y., \& Nauli, P. (2022). Pengaruh Partisipasi Anggaran terhadap Kinerja Karyawan dengan Budaya Organisasi dan Kepuasan Kerja Sebagai Variabel Intervening, Bank Rakyat Indonesia Kantor Cabang Bandar Lampung. Jurnal Studi Pemerintahan dan Akuntabilitas, 1(2), 97110.

\footnotetext{
1. Pendahuluan

Pertumbuhan ekonomi yang semakin meningkat maka semakin tinggi juga persaingan yang ada di dalamnya, begitupun yang terjadi di dalam dunia perbankan. Sektor Perbankan merupakan salah satu komponen yang berperan dalam kemajuan perekonomian Indonesia, sehingga kualitas dan kuantitas dari perbankan itu sendiri lebih diutamakan. Menurut Undang-Undang Perbankan Nomor 10 Tahun 1998, Bank ialah suatu sektor keuangan yang menghimpun dan menyalurkan dana dari masyarakat dan untuk masyarakat. Pada masa yang sekarang ini persaingan diantara bank semakin kuat, tiap bank berlomba-lomba untuk memperoleh nasabah, dari adanya persaingan yang terjadi antar bank tersebut maka pihak bank menuntut untuk berlomba-lomba dalam meningkatkan kinerja bank dan kinerja pelayanan.
}

Anggaran adalah bagian penting dari sebuah institusi, misalnya seperti institusi kecil, menengah serta go public. Sistem anggaran memberikan keuntungan bagi perusahaan. Menurut Hansen dan Mowen (2004: 1), keunggulan sistem anggaran yaitu sebuah perencanaan yang dapat mendukung pemimpin 
dalam meningkatkan tujuan suatu kelompok, mengantisipasi persoalan, serta meningkatkan kemahiran di waktu yang akan datang. Dan keunggulan lainnya dimana perencanaan tersebut mampu membenahi proses hasil akhir. Proses penyusunan anggaran memerlukan keikutsertaan dari masing-masing individu anggota karena keikutsertaan tiap individu tersebut akan memiliki pengaruh untuk pengambilan keputusan anggaran yang akan ditetapkan.

Kinerja karyawan yang baik akan meningkatkan kepuasan kerja yang baik juga. Oleh sebab itu, organisasi perlu menentukan jika karyawan termotivasi untuk melaksanakan kemampuan paling tinggi mereka. Menurut (Hameed dan Waheed, 2011) Kinerja karyawan berarti sebuah kreativitas dan evaluasi yang dilakukan oleh karyawan dan berpengaruh penting untuk perusahaan. Karena kinerja karyawan adalah suatu aset perusahaan yang perlu ditingkatkan. Dalam meningkatkan kinerja di perlukan beberapa faktor misalnya budaya organisasi. Budaya organisasi adalah aspek pendukung yang mampu meningkatkan kinerja.

Budaya adalah standar dan kualitas yang mengarahkan perilaku individu suatu kelompok. Setiap bagian anggota harus melakukan tindakan yang sesuai dengan peraturan budaya sehingga dapat menyesuaikan keadaan di sekitar. Menurut Robbin (1997: 288) Budaya organisasi merupakan konsep bersama yang diterima oleh bagian kelompok, sehingga konsep tersebut dijadikan sebagai pedoman. Hofstede et al. (1990) dan Ikhsan (2005: 32) mengemukakan bahwa nilai-nilai budaya dapat tercermin dalam berbagai perilaku. Berdasarkan hasil penelitian dibuktikan bahwa nilai dan praktik budaya merupakan faktor penting yang digunakan dalam praktik sehari-hari.

Kemampuan setiap individu dapat dipenuhi jika kepuasan kerja dijadikan faktor untuk mempengaruhi terciptanya kinerja dengan baik. Agar mendapatkan hasil yang baik dalam bekerja, setidaknya pimpinan dapat selalu melihat keadaan sekitar tempat pekerja, menjalankan tanggung jawabnya, seperti rekan kerja, atasan, keadaan lingkungan sekitar yang dapat mempengaruhi semangat individu untuk melaksanakan tugasnya. Terlihat bahwa beberapa perusahaan masih memiliki kelemahan dalam kinerja karyawannya, diantaranya karyawan yang kurang berinisiatif untuk mengajukan ide baru dan karyawan yang kurang memiliki ide untuk menyelesaikan masalah yang muncul di perusahaan.

Di beberapa perusahaan perbankan belum pernah diadakan penelitian kepuasan kerja, oleh karena itu bagian institusi belum mengetahui jika sebagian pekerja menyukai ataupun belum menyukai semua bagian pekerjaannya. Institusi belum mengetahui bagian mana yang diinginkan dan bagian mana yang belum diinginkan, oleh karena itu sebagian unit belum dapat memperbaiki bagian yang belum disukai oleh pekerja. Apabila terdapat bagian yang belum di inginkan oleh pekerja, keadaan tersebut bisa mempengaruhi pekerja menjadi tidak optimal, bisa menurunkan kinerja mereka, dan bahkan karyawan dapat meninggalkan pekerjaan.

Berdasarkan beberapa uraian di atas tentang partisipasi anggaran, budaya organisasi dan kepuasan kerja yang memiliki pengaruh terhadap kinerja, maka penulis tertarik untuk mengetahui ketiga variabel tersebut untuk diterapkan di Bank Rakyat Indonesia Kantor Cabang Bandar Lampung.

\section{Tinjauan pustaka dan pengembangan hipotesis Teori Atribusi}

Menurut (Ardiansah, 2003) teori atribusi menjelaskan mengenai faktor apa yang dapat memastikan timbulnya pemicu dari tindakan individu tersebut. Teori tersebut menjelaskan apakah penyebab dari tindakan masing-masing individu itu dapat disebabkan oleh pihak luar dan pihak dalam sehingga pengaruhnya dapat terlihat secara langsung. Dispositional attributions berfokus pada keadaan yang terdapat didalam diri individu, sedangkan Situasional attributions berfokus pada keadaan di sekitar untuk digunakan dalam tindakan individu.

\section{Akuntansi Keperilakuan}

Akuntansi keperilakuan ialah ilmu akuntansi dimana sudah mengalami peningkatan selama 25 tahun tearkhir. Penelitian akuntansi keperilakuan yaitu sebuah penemuan baru yang mempunyai hubungan secara langsung antara informasi akuntansi dengan audit. (Bonner and Penington (1991) mengemukakan bahwa Riset akuntansi keperilakuan dalam bidang audit mengalami perkembangan yaitu pada tinjauan literature yang digunakan telah menjadi spesialis dan lebih terfokuskan secara 
menyeluruh. Menurut Kusuma (2003) penelitian keperilakuan dengan karangan tertentu misalnya sebagai bidang pemeriksaan keuangan yang mampu memberikan partisipasi yang sangat berarti, dan penelitian tersebut mampu menciptakan sebuah kerangka dasar dimasa depan. Akuntansi perilaku memberikan penjelasan sebagaimana tindakan individu dapat berpengaruh pada suatu pendataan dan suatu penentuan hasil akhir.

\section{Partisipasi Anggaran}

Partisipasi adalah keikutsertaan individu secara langsung dalam sebuah kelompok untuk mencapai tujuan bersama. Menurut (Anthony serta Govindarajan, 2005) partisipasi yang dilakukan oleh masing masing kelompok tidak hanya berupa aktivitas fisik tetapi juga pada sisi psikologis, dimana seseorang dianggap memiliki pengaruh yang besar dalam pengambilan keputusan.

Menurut Nafarin ( 2004) anggaran merupakan sesuatu konsep keuangan tertentu yang dibuat berdasarkan pada keputusan yang sudah ditetapkan. Dalam proses tersebut kontribusi terbanyak akan terjalin bila karyawan dilibatkan untuk berpartisipasi secara langsung. Sama hal nya dengan yang dijelaskan oleh Hoque serta Peter (2007) anggaran merupakan kontribusi yang dilakukan karyawan dalam memutuskan anggaran akhir yang dituju.

Menurut Milani ( 1975) partisipasi anggaran ialah tingkat keikutsertaan ( involment) serta dampak (influence) karyawan untuk pengelolaan suatu anggaran. Partisipasi anggaran memakai 6 indeks yakni:

1. Keikutsertaan karyawan pada pengelola keuangan

2. Argumen pimpinan selama megoreksi keuangan yang diajukan.

3. Keinginan membagikan tanggapan

4. Dampak karyawan pada keuangan periodik

5. Berartinya partisipasi yang diberikan

6. pempinan selalu meminta komentar ataupun saran disaata keuangan sedang disusun

\section{Kinerja Karyawan}

Menurut George dan Jones ( 2005) kinerja merupakan penilaian dari hasil sikap seorang karyawan, misalnya untuk memastikan baik buruknya seseorang dalam melaksanakan tanggung jawabnya dalam sebuah pekerjaan. Sama hal nya dengan yang dijelaskan oleh (Harsuko, 2011) Kinerja merupakan pandangan seseorang untuk melaksanakan bagian tanggung jawabnya dalam organisasi, untuk mencapai suatu tujuan yang berhubungan secara langsung sebagai anggota dan menunjukkan kemampuan yang dinyatakan relevan bagi institusi.

Kinerja karyawan merupakan suatu aktivitas pengembangan yang dilakukan seorang karyawan untuk mencapai nilai suatu produk (Hameed serta Wahed, 2011). Menurut Sinambela et.al.( 2012) kinerja karyawan berarti suatu kemampuan yang dimiliki pada individu dalam melakukan tugas dan tanggung jawabnya. Dalam menentukan karakteristik yang sesuai maka dapat diputuskan secara bersamaan dan dapat digunakan untuk gambaran.

Menurut Burney, Henle serta Widener( 2009) kinerja karyawan bisa dilihat melalui 7 indeks ialah:

1. Mutu penugasan

2. Kewajiban

3. Penerapan pekerjaan

4. paham dengan kebijakan

5. berkontribusi pada kegiatan

6. waspada dalam bertugas

7. Kesuksesan melaksanakan pekerjaan

\section{Budaya Organisasi}

Budaya organisasi adalah serangkaian nilai serta strategi, gaya kepemimpinan, visi serta misi dan norma- norma keyakinan serta penafsiran yang menjadi acuan untuk anggota organisasi dan dianggap sebagai kebaikan untuk anggota baru pada struktur kerja di lapangan dalam meciptakan kepribadian seseorang. Dalam menentukan keberhasilan bagi organisasi diperlukan tindakan yang bisa dilakukan 
untuk kekuatan dalam persaingan. Budaya organisasi dijadikan sebagai tujuan penting apabila budaya organisasi memenuhi suatu strategi organisasi, dan budaya organisasi dalam menghadapi masalah secara tepat serta cepat.

Pada penjelasan tersebut bisa disimpulkan bahwa budaya organisasi ialah seperangkat anggapan ataupun sistem kepercayaan, nilai, serta kebiasaan yang diikuti oleh tiap individu atau kelompok yang dapat digunakan sebagai petunjuk untuk merubah sikap dalam menanggulangi permasalahan.

Menurut Robbins dan Judge (2015) organisasi mempunyai 7 karakter yang dapat dijadikan sebagai indikator dalam penelitian, yakni:

1. Pengembangan dan pengambilan resiko.

2. Peduli pada hal hal yang detail (ketelitian)

3. Arah pencapaian

4. Arah individu

5. Pengarahan kelompok

6. Terencana

7. Kekuatan

\section{KepuasanKerja}

Menurut Jex (2002), kepuasan kerja seperti“ tingkatan afeksi positif seseorang pekerja terhadap pekerjaan dan situasi pekerjaan.” Kepuasan kerja senantiasa berhubungan langsung pada perilaku pekerja, atas pekerjaannya tersebut dalam aspek kognitif serta tingkah laku. Aspek kognitif kepuasan kerja adalah keyakinan individu mengenai kondisi pekerjaanya bahwa pekerja meyakini pekerjaan tersebut sangat menarik atau tidak. Aspek perilaku pekerjaan merupakan keinginan tindakan karyawan terhadap kinerja yang ditampilkan melalui tugas dan tanggung jawabnya, mampu bertahan sesuai tugasnya, atau melaksanakan tugasnya dengan teratur dan disiplin.

Kepuasan kerja yaitu tingkat pengaruh positif yang dimiliki karyawan atas situasi pekerjaannya (Locke, 1976). Menurut (Handoko, 2014) kepusan kerja ialah suatu sifat yang dimiliki oleh pekerja dalam menilai tugas dan tanggung jawabnya. Kepuasan kerja menjelaskan mengenai anggapan individu tentang pekerjaannya. Kepuasan kerja tersebut akan terlihat dalam sikap positif karyawan terhadap pekerjaan dan semua materi yang ditemui dilingkungan tempat bekerja.

Kepuasan kerja diukur dengan memakai 5 indeks yang mengacu dari riset Stephen P. Robbins ( 2008: 110) yaitu:

1. Pembayaran pendapatan ataupun gaji

2. tanggungjawab pekerjaan

3. teman bekerja

4. peningkatan

5. pimpinan

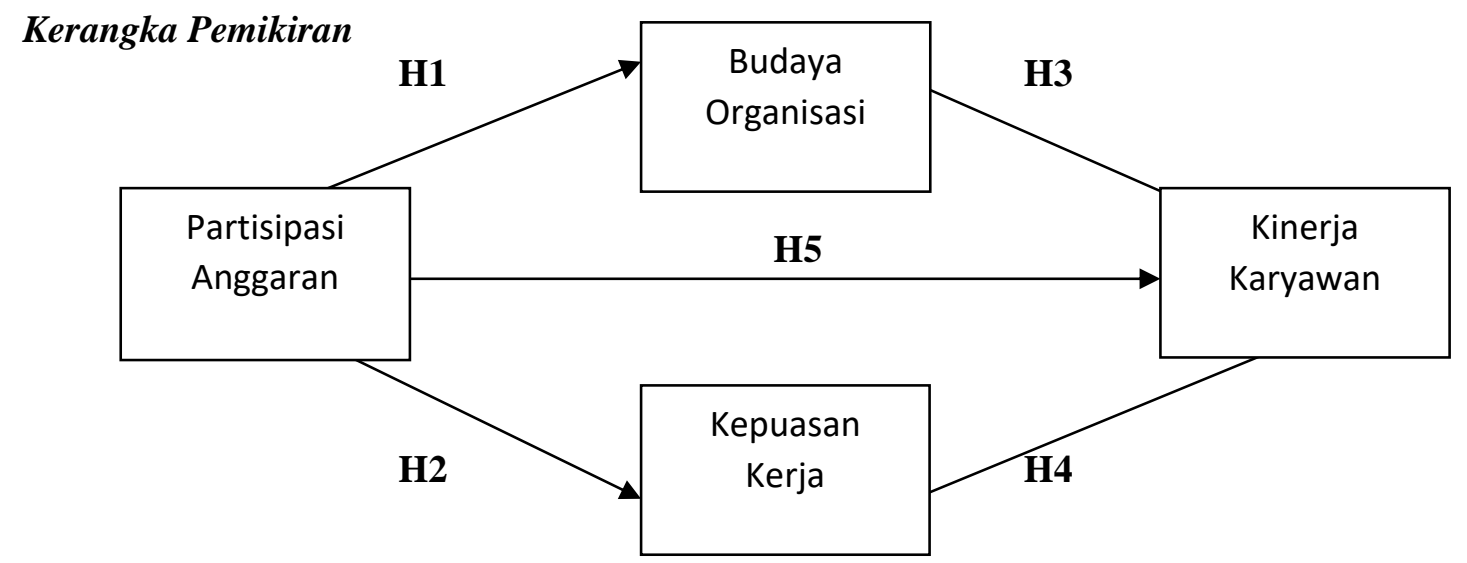

Gambar 1. KerangkaPemikiran 


\section{Pengembangan Hipotesis}

Seperti yang dijelaskan oleh Holmes serta Marsden (1996), budaya organisasi mempengaruhi tingkah laku, strategi kerja serta inspirasi dari pimpinan dan bawahan agar tercapai suatu kinerja organisasi. Berdasarkan riset yang berkaitan dengan budaya, dikatakan jika ukuran budaya mempengaruhi terhadap partisipasi pengelolaan anggaran dalam peningkatan kinerja. Dari uraian tersebut, hipotesis yang bisa diambil ialah:

\section{H1: Partisipasi anggaran mempengaruhi positif terhadap budaya organisasi.}

Abriani (1998) berpendapat bahwa adanya sebuah hubungan antara pengaruh partisipasi dengan penyusunan anggaran terhadap kepuasan dalam bekerja. Dalam riset ini ditemui positif yang menampilkan koneksi yang searah antara partisipasi anggaran dengan kepuasan kerja, sehingga bisa dinyatakan apabila partisipasi semakin besar dalam pengelolaan anggaran maka kepuasan kerjapun menjadi besar. Dari uraian tersebut, hipotesis yang bisa diambil ialah:

\section{$\mathrm{H} 2$ : partisipasi anggaran berpengaruh positif terhadap kepuasan kerja}

Budaya organisasi di suatu institusi membentuk suatu cara untuk menyatukan semua individu apabila melaksanakan kegiatan secara bersamaan. (Kreitner serta Kinicki, 2001: 532): berpendapat jika budaya organisasi merupakan perekat sosial yang mengikat anggota dari organisasi, meskipun memiliki ciri dan karakter yang berbeda- beda antara yang satu dengan yang lain bisa disatukan dalam suatu kekuatan organisasi. Keutamaan budaya organisasi ialah pengendalian serta arah dalam membentuk sikap manusia yang mengaitkan diri dalam sesuatu aktivitas organisasi. Budaya memiliki kekuatan penuh, mempengaruhi individu pada kinerjanya terhadap kawasan bekerja. Hasil penelitian Putri, Yuliansyah dan Pigo (2021) menunjukkan adanya pengaruh positif antara faktor budaya organisasi dan berdampak signifikan terhadap kinerjanya. Sedangkan penelitian yang dilakukan oleh Prayoga dan Zulvia (2021) menunjukkan budaya organisasi berpengaruh signifikan dan positif secara parsial terhadap kinerja karyawan. Dari uraian tersebut, hipotesis yang bisa diambil ialah:

\section{H3: budaya organisasi berpengaruh positif terhadap kinerja karyawan.}

Listianto serta Setiaji( 2007) mengemukakan bahwa kepuasan kerja memiliki pengaruh positif serta signifikan terhadap kinerja. Lawler( 2003) menjelaskan bahwa terdapat ikatan positif antara kepuasan kerja dengan kinerja organisasi. Riset ini pula dikuatkan oleh Verawati( 2009) yang beralasan bahwa kepuasan kerja mempengaruhi secara positif terhadap kinerja organisasi. Sedangkan riset Mehamba( 2014) menjelaskan juga bahwa kepuasan kerja tidak mempengaruhi secara signifikan terhadap kinerja karyawan." Dari uraian tersebut, hipotesis yang bisa diambil ialah:

H4: kepuasan kerja berpengaruh positif terhadap kinerja karyawan.

Menurut Mah'detal (2013), seseorang yang berkontribusi didalam anggaran secara langsung mempunyai faktor kinerja yang sangat baik apabila dibandingkan dengan seseorang yang tidak berkontribusi dalam penyusunan anggaran. Menurut (Wong On Wing, Lan, dan Lui, 2010) Partisipasi anggaran telah mempengaruhi kinerja seseorang dan kepuasan kerja pada individu, pegawai tersebut menjadi senang apabila kontribusi dari mereka diterima bagi pimpinan. Dalam penelitian yang dilakukan oleh (Yahya, Nor. NikAhmad dan Fatima 2008) adanya hubungan positif dan signifikan antara partisipasi penyusunan anggaran dan kinerja manajerial. Sedangkan riset (Adelin, Kiagus dan Niken, 2021) menjelaskan juga bahwa partisipasi anggaran tidak mempengaruhi secara signifikan terhadap kinerja karyawan. Oleh karena itu, hipotesis yang di peroleh adalah:

H5: partisipasi anggaran berpengaruh positif terhadap kinerja karyawan. 


\section{Metode penelitian}

\section{Jenis Penelitian}

Strategi peneliti yang penulis gunakan merupakan metode penelitian fasosiatif. Metode tersebut dimanfaatkan untuk mengukur nilai suatu varibel bebas dan variabel terikat. (Sugiyono, 2003).

\section{Data dan Variabel}

Data informasi yang didapat yaitu seluruh pekerja Bank Rakyat Indonesia Cabang Bandar Lampung. Variabel bebas yang terdapat pada penelitian tersebut ialah Partisipasi anggaran. Variabel reliabel adalah Kinerja karyawan. Variabel perantara adalah Budaya organisasi dan Kepuasan kerja.

\section{Populasi dan SampelPenelitian}

Populasi dalam peneitian ini adalah para pekerja PT Bank Rakyat Indonesia Kantor Cabang Bandar Lampung. Seperti yang dijelaskan oleh Arikanto (2010), untuk menentukan subjek di bawah 100, sebaiknya diambil semua dengan tujuan agar penelitian tersebut menjadi populasi. Kemudian, seperti yang dijelaskan oleh Sugiyono (2003), jika populasinya besar dan penelitiannya tidak terjangkau untuk mempelajari semua yang ada dalam populasi. Sampel yang digunakan ialah karyawan PT Bank Rakyat Indonesia Kantor Cabang Bandar Lampung.

Karyawan dipilih sesuai dengan tujuan (standar yang diinginkan). Contoh karakteristik pilihan dalam penelitian ini adalah sebagai berikut:

1. Karyawan yang bekerja $>1$ tahun,

2. Bersedia mengisi seluruh pertanyaan secara tepat dan efektif.

3. Pernah terlibat dengan penyusunan anggaran

\section{MetodePengumpulan Data}

Metode pengumpulan yang digunakan dalam penelitian ini adalah metode observasi. Penelitian menampilkan daftar pertanyaan (data lapangan) untuk mendapatkan informasi mendasar tentang masalah yang sedang diselidiki dan responden diharapkan untuk mengisi seperti yang telah ditunjukkan dalam daftar pertanyaan. Penggunaan skala yang memanfaatkan jenis informasi yang dipakai ialah nilai pernyataannya terhitung mulai: $1=$ Sangat Tidak Setuju, $2=$ Setuju, $3=$ Netral, $4=$ Setuju, $5=$ Sangat Setuju, (Ghozali, 2011).

\section{Metode Analisa Data}

Analisis yang digunakan peneliti yaitu dengan memakai metode Struktural Equation Modeling (SEM). Dalam menganalisis hasil yang diperoleh oleh peneliti yaitu dengan cara memakai alat pendekatan Partial Least Square (PLS) karena PLS adalah sebuah pendekatan alternatif yang bergeser dari pendekatan SEM berbasis covariance menjadi basis varian. Untuk menganalisis penelitian tersebut, peneliti mengggunakan PLS karena PLS dianggap sebagai software yang sangat baik dan efesien untuk dipakai dalam menghasilkan data yang memiliki < 100 responden (Ghozali, 2011). Teknik analisis data dipakai dalam menentukan sebuah masalah atau hipotesis yang telah dibuat. Cara analisis hasil yang dipakai pada peneliti adalah :

\section{Uji validitas}

Uji validitas merupakan uji yang dipakai untuk mengetahui apakah pertanyaan yang ada pada kuesioner tersebut dapat benar benar di uji (Ghozali, 2011). Pengujian validitas yang dilakukan peneliti ini dengan cara menghitung Partial Least Square (PLS) yaitu menghitung nilai validitas konvergen lalu validitas diskriminan. Cara menghitung validitas konvergen yaitu menggunakan cara memantau hasil akhir Average Variance Ekstracted (AVE). apabila nilai AVE mencapai skor sebesar 0,5 maka nilai konvergen tersebut dikatakan sangat baik. Tujuan validitas diskriminan yaitu, apakah terdapat keunikan dalam suatu item dengan konstruk lainnya. Validitas diskriminan tersebut diperoleh melalui dua cara yaitu Fornell-Larcker dan Cross Loading.

\section{Uji Reliabilitas}

Uji reliabilitas dilihat guna mengenali hasil pengukuran senantiasa konsisten apabila dicoba pengukuran lebih dari 2 kali dengan memakai alat ukur yang sama. Pengujian reliabilitas dilakukan dengan Partial 
Least Square ( PLS), apabila suatu kuesioner dikatakan handal jika jawaban dari responden tersebut konsisten dari waktu ke waktu (Ghozali, 20011). Uji reliabilitas yang dilakukan dengan uji Cronbach Alpha. Suatu konstruk atau variabel dikatakan handal jika memberikan nilai Cronbach Alpha lebih dari 0,70 (Ghozali, 2011).

\section{Pengukuran Struktural Model}

Dalam penulisan pembukuan, model penelitian menggunakan teknik Coefficient of determinantion dan Path Coefficient (Cenhall, 2004), seperti halnya penelitian ini juga menggunakan kedua strategi ini.

1. Coefficient Of Determinantion $\left(\mathrm{R}^{2}\right)$

Uji pengukuran dilakukan agar mendapatkan hasil bahwa konstruk endogen harus menguatkan jalinan hubungan dengan konstruk eksogen dan mengevaluasi $\mathrm{R}^{2} . \mathrm{R}^{2}$ berfungsi untuk mengukur hubungan variabel laten dengan variabel varians. Seperti yang diungkapkan dalam penelitian sebelumnya, estimasi $\mathrm{R}^{2}$ dengan variabel endogen di atas 0,1 layak diterima (Chenhall, 2004).

2. Path Coefficient

Uji Koefisien dilakukan untuk menjamin bahwa hubungan antara konstruk adalah kuat. Strategi tersebut memakai teknik bootstrap dengan mendapatkan nilai 500 pergantian (Chenhall, 2004: Sholihin et al., 2010). Pengaruh antara konstruk dibilang kuat jika path coefficient lebih besar dari 0,100. Selain itu, hubungan antara faktor-faktor internal dianggap penting jika koefisien jalan mencapai di tingkat 0,050 (Urbach dan Ahleman, 2010).

\section{Uji Hipotesis}

Dalam melakukan uji hipotesis partisipasi anggaran, budaya organisasi, kepuasan kerja dan kinerja karyawan bisa dicoba memakai cara membandingkan antara hasil path coefficient dengan $\mathrm{T}$ tabel. Teori tersebut cukup dibilang sangat signifikan jika $\mathrm{T}$ hitung $>\mathrm{T}$ tabel pada tingkat kebebasan $1 \%$. Teori tersebut dianggap signifikan jika $\mathrm{T}$ hitung $>\mathrm{T}$ tabel pada tingkat kebebaan 5\% dan dengan asumsi $\mathrm{T}$ hitung $>\mathrm{T}$ tabel pada tingkat peluang 10\%, hipotesis dianggap lemah. Sementara itu hipotesis dianggap tidak signifikan jika $\mathrm{T}$ hitung $<\mathrm{T}$ tabel pada kebebasan 10\%. ( Hartono, 2015).

\section{Hasil dan pembahasan}

Objek penelitian ini ialah para karyawan PT Bank Rakyat Indonesia Kantor Cabang Bandar Lampung yang pernah terlibat pada pengelolaan anggaran atau tidak pernah diikutsertakan. Penelitian ini memakai data primer dimana informasi yang diperoleh secara langsung dari lapangan. Jumlah kuesioner yang tersebar adalah 100 di Bank Rakyat Indonesia. Kuesioner yang dikembalikan adalah 80 menggunakan tingkat pengembalian $80 \%$ dan 20 kuesioner yang tidak dikembalikan menggunakan tingkat pengembalian $20 \%$. Estimasi perhitungan polling dalam tabel ini :

Tabel 1. Persentase Pengiriman dan Pengembalian Kuesioner

\begin{tabular}{|c|c|c|c|}
\hline No & Keterangan & Jumlah & Persentase \\
\hline 1 & Polling disebarluaskan & 100 & $100 \%$ \\
\hline 2 & Polling menghasilkan & 80 & $80 \%$ \\
\hline 3 & pendapat yang tidak dikembalikan & 20 & $20 \%$ \\
\hline & Survei Disiapkan & $\mathbf{8 0}$ & $\mathbf{8 0 \%}$ \\
\hline
\end{tabular}

Tabel 2. Deskriptif Data

\begin{tabular}{|c|c|c|c|c|c|c|c|c|}
\hline \multirow[t]{2}{*}{ Variabel } & \multirow[t]{2}{*}{ Dimensi } & \multirow[t]{2}{*}{$\mathrm{N}$} & \multicolumn{2}{|c|}{ Nilai Teori } & \multicolumn{2}{|c|}{$\begin{array}{c}\text { Nilai } \\
\text { Sebenarnya }\end{array}$} & \multirow[t]{2}{*}{ Median } & \multirow[t]{2}{*}{ Modus } \\
\hline & & & Min & Maks & Min & Maks & & \\
\hline & 1. keikutsertaan & & 1 & 5 & 1 & 5 & 3 & 3 \\
\hline & $\begin{array}{l}\text { Perbaikan } \\
\text { Anggaran }\end{array}$ & & 1 & 5 & 1 & 5 & 4 & 5 \\
\hline
\end{tabular}

2022 | Jurnal Studi Pemerintahan dan Akuntabilitas (Jastaka)/ Vol 1 No 2, 97-110. 


\begin{tabular}{|c|c|c|c|c|c|c|c|c|}
\hline \multirow{4}{*}{$\begin{array}{l}\text { Partisipasi } \\
\text { Anggaran }\end{array}$} & $\begin{array}{l}\text { 3. kebutuhan } \\
\text { memberikan saran }\end{array}$ & \multirow{4}{*}{80} & 1 & 5 & 1 & 5 & 4 & 3 \\
\hline & $\begin{array}{l}\text { 4. finalisasi } \\
\text { Anggaran }\end{array}$ & & 1 & 5 & 1 & 5 & 4 & 3 \\
\hline & 5. ikut langsung & & 1 & 5 & 1 & 5 & 4 & 5 \\
\hline & 6. opini & & 1 & 5 & 1 & 5 & 4 & 5 \\
\hline \multirow{3}{*}{$\begin{array}{l}\text { Kinerja } \\
\text { Karyawan }\end{array}$} & 1. keahlian & & 1 & 5 & 1 & 5 & 4 & 5 \\
\hline & $\begin{array}{l}\text { 2. keefektifan serta } \\
\text { efesien }\end{array}$ & & 1 & 5 & 1 & 5 & 5 & 5 \\
\hline & $\begin{array}{c}3 . \\
\text { kekuasaan\&Tanggu } \\
\text { ngjawab }\end{array}$ & & 1 & 5 & 1 & 5 & 5 & 5 \\
\hline \multirow{7}{*}{$\begin{array}{l}\text { Budaya } \\
\text { Organisasi }\end{array}$} & $\begin{array}{c}\text { 1. Perubahan } \\
\text { pemungutan akibat }\end{array}$ & \multirow{7}{*}{80} & 1 & 5 & 1 & 5 & 5 & 5 \\
\hline & 2. Agresivitas & & 1 & 5 & 1 & 5 & 5 & 5 \\
\hline & 3. hasil tujuan & & 1 & 5 & 1 & 5 & 5 & 5 \\
\hline & 4. tujuan tim & & 1 & 5 & 1 & 5 & 5 & 5 \\
\hline & $\begin{array}{l}\text { 5. perhatian } \\
\text { kerincian }\end{array}$ & & 1 & 5 & 1 & 5 & 5 & 5 \\
\hline & 6. stabilitas & & 1 & 5 & 1 & 5 & 5 & 5 \\
\hline & 7. orientasi orang & & 1 & 5 & 1 & 5 & 5 & 5 \\
\hline \multirow{5}{*}{$\begin{array}{c}\text { Kepuasan } \\
\text { kerja }\end{array}$} & 1. pembayaran gaji & \multirow{5}{*}{80} & 1 & 5 & 1 & 5 & 5 & 5 \\
\hline & $\begin{array}{l}\text { 2. pekerjaan itu } \\
\text { sendiri }\end{array}$ & & 1 & 5 & 1 & 5 & 5 & 5 \\
\hline & 3. rekan kerja & & 1 & 5 & 1 & 5 & 5 & 5 \\
\hline & 4. Promosi & & 1 & 5 & 1 & 5 & 5 & 5 \\
\hline & 5. atasan & & 1 & 5 & 1 & 5 & 5 & 5 \\
\hline
\end{tabular}

Tabel 3. Deskriptif Responden

\begin{tabular}{|c|c|c|c|c|c|}
\hline & & N & $\%$ & Valid Percent & CumulativePercent \\
\hline Jenis kelamin & Laki-Laki & 44 & $55,0 \%$ & $55,0 \%$ & $55,0 \%$ \\
\hline
\end{tabular}




\begin{tabular}{|c|c|c|c|c|c|}
\hline & Perempuan & 36 & $45,0 \%$ & $45,0 \%$ & $100 \%$ \\
\hline & Jumlah & & & $100 \%$ & \\
\hline \multirow{4}{*}{ Usia } & $<30$ & 33 & $41,3 \%$ & $41,3 \%$ & $41,3 \%$ \\
\hline & $31-45$ & 28 & $35,0 \%$ & $35,0 \%$ & $76,3 \%$ \\
\hline & $46-55$ & 19 & $23,8 \%$ & $23,8 \%$ & $100 \%$ \\
\hline & Total & & & $100 \%$ & \\
\hline \multirow{3}{*}{$\begin{array}{l}\text { Pendidikan } \\
\text { Terakhir }\end{array}$} & Diploma/D3 & 22 & $27,5 \%$ & $27,5 \%$ & $27,5 \%$ \\
\hline & Sarjana/S1 & 58 & $72,5 \%$ & $72,5 \%$ & $100 \%$ \\
\hline & Total & & & $100 \%$ & \\
\hline \multirow[t]{6}{*}{ Devisi Kerja } & Mantri & 30 & $37,5 \%$ & $37,5 \%$ & $37,5 \%$ \\
\hline & PAB & 6 & $7,5 \%$ & $7,5 \%$ & $70,0 \%$ \\
\hline & SPO & 7 & $8,8 \%$ & $8,8 \%$ & $62,5 \%$ \\
\hline & Teller & 13 & $16,3 \%$ & $16,3 \%$ & $53,8 \%$ \\
\hline & $\begin{array}{c}\text { Jabatan yang } \\
\text { lainnya }\end{array}$ & 24 & $30,0 \%$ & $30,0 \%$ & $100 \%$ \\
\hline & Jumlah & & & $100 \%$ & \\
\hline
\end{tabular}

mengenai informasi responden penelitian dapat dicermati bahwa responden penelitian cenderung seimbang dengan kontributor laki-laki yaitu dengan jumlah 44 orang $(55 \%) \&$ kontributor perempuan berjumlah 36 responden $(45 \%)$ menurut total 80 responden. Dilihat berdasarkan usia, secara umum dikuasai responden berusia $<30$ sebanyak 33 responden atau (41\%), usia 31-45 tahun sebesar 28 responden atau (35\%), usia 46-55 sebanyak 19 responden atau (24\%). Jika dicermati menurut pendidikan terakhir, responden mempunyai pendidikan terakhir Diploma sebesar 22 responden atau (27\%) dan Sarjana (S1) yaitu 58 responden atau (72\%) menurut total keseluruhan. Dari tabel tersebut juga bisa diamati jika kontributor dalam penelitian tersebut 30 orang divisi Mantri dengan tingkat persentase $(37 \%), 6$ orang divisi PAB menggunakan taraf persentase (7\%), 7 orang divisi SPO menggunakan tingkat persentase (8\%), 13 orang divisi Teller menggunakan tingkat persentase $(16 \%)$, dan 24 orang divisi lainnya dengan tingkat persentase (30\%).

Tabel 4. Uji Reliabilitas

\begin{tabular}{|c|c|c|c|c|}
\hline & AVE & CompositeReliability & $\boldsymbol{R}$ Square & Cronbach'sAlpha \\
\hline Partisipasi Anggaran & 0,894 & 0,981 & & 0,976 \\
\hline Budaya Organisasi & 0,767 & 0,958 & 0,183 & 0,949 \\
\hline Kepuasan Kerja & 0,738 & 0,934 & 0,271 & 0,911 \\
\hline Kinerja Karyawan & 0,544 & 0,871 & 0,720 & 0,812 \\
\hline
\end{tabular}

Pemeriksaan relibilitas konstruk adalah menggunakan Cronbach's Alpha atau hasil composite reliability lebih dari 0.7 , dalam tabel diatas menampakan reliabilitas konstruk yang ditinjau berdasarkan nilai cronbach'salpha dan composite reliability. 
Tabel 5. Uji Validitas Konvergen

\begin{tabular}{|c|c|}
\hline & AVE \\
\hline & $\mathbf{0 , 8 9 4}$ \\
\hline Partisipasi Anggaran & $\mathbf{0 , 7 6 7}$ \\
\hline Budaya Organisasi & $\mathbf{0 , 7 3 8}$ \\
\hline Kepuasan Kerja & $\mathbf{0 , 5 4 4}$ \\
\hline Kinerja Karyawan &
\end{tabular}

Dapat dilihat dalam Tabel diatas jika semua konstruk penelitian mempunyai skor AVE bertambah berdasarkan 0,5.kondisi tersebut dapat diartikan jika semua konstruk penelitian mempunyai nilai validitas yang baik.

Tabel 6. Uji Validitas Diskriminan

\begin{tabular}{|c|c|c|c|c|}
\hline & $\begin{array}{l}\text { Partisipasi } \\
\text { Anggaran }\end{array}$ & $\begin{array}{c}\text { Budaya } \\
\text { Organisasi }\end{array}$ & Kepuasan Kerja & $\begin{array}{c}\text { Kinerja } \\
\text { Karyawan }\end{array}$ \\
\hline PA1 & 0,951 & 0,391 & 0,476 & 0,480 \\
\hline PA2 & 0,934 & 0,459 & 0,500 & 0,570 \\
\hline PA3 & 0,968 & 0,332 & 0,442 & 0,448 \\
\hline PA4 & 0,951 & 0,394 & 0,464 & 0,429 \\
\hline PA5 & 0,955 & 0,398 & 0,516 & 0,468 \\
\hline PA6 & 0,912 & 0,431 & 0,537 & 0,553 \\
\hline BO1 & 0,374 & 0,885 & 0,692 & 0,758 \\
\hline BO2 & 0,414 & 0,884 & 0,702 & 0,790 \\
\hline BO3 & 0,306 & 0,852 & 0,699 & 0,632 \\
\hline BO4 & 0,339 & 0,833 & 0,658 & 0,533 \\
\hline BO5 & 0,333 & 0,901 & 0,691 & 0,699 \\
\hline BO6 & 0,400 & 0,921 & 0,729 & 0,781 \\
\hline BO7 & 0,433 & 0,852 & 0,713 & 0,729 \\
\hline KP1 & 0,569 & 0,710 & 0,905 & 0,732 \\
\hline KP2 & 0,417 & 0,721 & 0,894 & 0,689 \\
\hline KP3 & 0,368 & 0,715 & 0,855 & 0,690 \\
\hline KP4 & 0,377 & 0,701 & 0,824 & 0,577 \\
\hline KP5 & 0,482 & 0,581 & 0,815 & 0,608 \\
\hline KK1 & 0,453 & 0,688 & 0,618 & 0,832 \\
\hline KK2 & 0,017 & 0,127 & 0,195 & 0,095 \\
\hline KK3 & 0,493 & 0,637 & 0,693 & 0,902 \\
\hline KK4 & 0,510 & 0,547 & 0,496 & 0,770 \\
\hline KK5 & 0,047 & 0,255 & 0,254 & 0,235 \\
\hline KK6 & 0,410 & 0,832 & 0,734 & 0,901 \\
\hline KK7 & 0,465 & 0,759 & 0,714 & 0,913 \\
\hline
\end{tabular}

Dimana PA1 0,951; PA2 0,934; PA3 0,968; PA4 0,951; PA5 0,955; PA6 0.912, nilai korelasi konstruk PA lebih tinggi dari pada nilai konstruk yang lain. Oleh karena itu konstruk tersebut mempunyai nilai validitas diskriminan yang baik. Begitu pula, dalam melihat nilai kuadrat antara konstruk dengan nilai AVE atau korelasi antara konstruk dengan akar AVE. 
Tabel 7. Fornell-LarckerCorelation

\begin{tabular}{|l|l|l|l|l|}
\hline & PA & BO & KP & KK \\
\hline PA & $\mathbf{0 , 9 4 5}$ & & & \\
\hline BO & 0,428 & $\mathbf{0 , 8 7 6}$ & & \\
\hline KP & 0,521 & 0,797 & $\mathbf{0 , 8 5 9}$ & \\
\hline KK & 0,525 & 0,812 & 0,771 & $\mathbf{0 , 7 3 8}$ \\
\hline
\end{tabular}

Terlihat hubungan konstruk Partisipasi anggaran dengan konstruk lainnya adalah 0,945. Sedangkan korelasi maksimal budaya organisasi adalah 0,876 , kepuasan kerja adalah 0,859 \& kinerja karyawan adalah 0,738 . Hal ini menyimpulkan apabila konstruk mempunyai skor bertambah dari konstruk yang lain. Jadi konstruk tersebut mempunyai skor validitas yang baik.

Tabel 8. Pengukuran Struktural Model

\begin{tabular}{|c|c|c|c|c|}
\hline \multirow{2}{*}{$\begin{array}{c}\text { Variabel } \\
\text { Dependent }\end{array}$} & \multicolumn{3}{|c|}{ Variabel Independent } & \multirow[t]{2}{*}{$\mathrm{R}^{2}$} \\
\hline & $\begin{array}{l}\text { Partisipasi } \\
\text { Anggaran }\end{array}$ & Budaya Organisasi & Kepuasan Kerja & \\
\hline $\begin{array}{c}\text { Budaya } \\
\text { Organisasi }\end{array}$ & $\begin{array}{c}\mathbf{0 , 4 2 8} \\
(\mathbf{5}, \mathbf{2 7 2})^{* * * *}\end{array}$ & & & $\mathbf{0 , 1 8 3}$ \\
\hline $\begin{array}{c}\text { Kepuasan } \\
\text { Kerja }\end{array}$ & $\begin{array}{c}\mathbf{0 , 5 2 1} \\
(\mathbf{8}, \mathbf{0 2 7})^{* * *}\end{array}$ & & & 0,271 \\
\hline $\begin{array}{c}\text { Kinerja } \\
\text { Karyawan }\end{array}$ & $\begin{array}{c}\mathbf{0 , 1 6 0} \\
(2,187)^{*}\end{array}$ & $\begin{array}{c}0,536 \\
(4,036) * * *\end{array}$ & $\begin{array}{c}\mathbf{0 , 2 6 0} \\
(1,892)^{*}\end{array}$ & 0,720 \\
\hline
\end{tabular}

Terlihat bahwa nilai estimasi $\mathrm{R}^{2}$ sesuai dengan budaya organisasi, kepuasan kerja dan kinerja karyawan adalah 0,$183 ; 0,271 ; 0.720$. karakteristik nilai estimasi $\left(\mathrm{R}^{2}\right)$ seharusnya dapat diterima jika memiliki nilai estimasi $\mathrm{R}^{2}$ lebih dari 0,1 dan berlandaskan pada sumber tersebut, maka dapat dikatakan bahwa Coefficient of determination dalam pengujian ini dapat dicapai sehingga tahap selanjutnya adalah menguji hipotesis.

Tabel 9. PathCoefficients (Mean, STDEV, T-Values)

\begin{tabular}{|c|c|c|c|c|c|c|}
\hline & $\begin{array}{c}\text { OriginalS } \\
\text { ample (O) }\end{array}$ & $\begin{array}{c}\text { Sample } \\
\text { Mean }\end{array}$ & $\begin{array}{c}\text { StandartDe } \\
\text { viation }\end{array}$ & $\begin{array}{c}\text { T Statistics } \\
(|\mathrm{O}| \text { STERR } \mid)\end{array}$ & $\begin{array}{c}\text { P } \\
\text { Value }\end{array}$ & Hasil \\
\hline PA -> BO & 0,428 & 0,435 & 0,081 & 5,272 & 0,000 & Terdukung \\
\hline PA -> KP & 0,521 & 0,529 & 0,065 & 8,027 & 0,000 & Terdukung \\
\hline BO -> KK & 0,536 & 0,542 & 0,133 & 4,036 & 0,000 & Terdukung \\
\hline KP -> KK & 0,260 & 0,256 & 0,137 & 1,892 & 0,059 & Terdukung \\
\hline PA -> KK & 0,160 & 0,162 & 0,073 & 2,187 & 0,029 & Terdukung \\
\hline
\end{tabular}

Tabel 10. Rangkuman Hasil Hipotesis

\begin{tabular}{|c|c|c|}
\hline Hipotesis & Deskripsi & Hasil \\
\hline 1 & Partisipasi Anggaran berpengaruh positif terhadap Budaya & Terdukung \\
& Organisasi $(=0,28, \mathrm{t}=5,272, \mathrm{p}<0,1)$ & \\
\hline 2 & $\begin{array}{c}\text { Partisipasi Anggaran berpengaruh positif terhadap Kepuasan } \\
\text { Kerja }(=0,521, \mathrm{t}=8,027 \mathrm{p}<0,1)\end{array}$ & Terdukung \\
\hline
\end{tabular}




\begin{tabular}{|c|c|c|}
\hline 3 & $\begin{array}{c}\text { Budaya Organisasi berpengaruh positif terhadap Kinerja } \\
\text { Karyawan }(=0,536, \mathrm{t}=4,036, \mathrm{p}<0,1)\end{array}$ & Terdukung \\
\hline 4 & $\begin{array}{c}\text { Kepuasan Kerja berpengaruh positif terhadap Kinerja Karyawan } \\
(=0,260, \mathrm{t}=1,892, \mathrm{p}<0,1)\end{array}$ & Terdukung \\
\hline 5 & $\begin{array}{c}\text { Partisipasi Anggaran berpengaruh positif terhadap Kinerja } \\
\text { Karyawan }(=0,160 . \mathrm{t}=2,187 . \mathrm{p}<0,1)\end{array}$ & Terdukung \\
\hline
\end{tabular}

Bersumber pada pemeriksaan tersebut, diketahui jika kerja sama terhadap karyawan amat sangat penting di sebuah perusahaan, karena akan meningkatkan kinerja karyawan. Dengan kontribusi perencanaan, karyawan akan lebih terbujuk untuk bekerja dan memiliki kewajiban kepada organisasi. Budaya organisasi memberikan pengaruh secara langsung, sehingga budaya mempengaruhi seorang pekerja. kepuasan pekerjaan mempengaruhi kinerja pekerja, oleh karena itu kepuasan pekerjaan berpengaruh secara signifikan.

\section{Kesimpulan}

Hasil pengelohan informasi serta ulasan yang telah dipaparkan peneliti. Sehingga peneliti merumuskan kesimpulan sebagai berikut :

1. Partisipasi anggaran mempengaruhi secara langsung terhadap kinerja karyawan. Riset tersebut menemukan sebenarnya partisipasi anggaran mempengaruhi secara positif pada kinerja karyawan. kinerja karyawan tersebut akan semakin baik jika karyawan memiliki tingkat partisipasi yang sangat besar saat penyusunan anggaran.

2. Partisipasi anggaran mempengaruhi individu terhadap budaya organisasi dan kepuasan kerja, penelitian ini menampilkan bahwa partisipasi anggaran mempengaruhi terhadap budaya organisasi ataupun terhadap kepuasan kerja. Hal tersebut menerangkan apabila seorang yang berpartisipasi pada penyusunan anggaran cenderung memiliki budaya pada bekerja dan mempunyai rasa kepuasan kerja terhadap industri.

\section{Limitasi dan Studi lanjutan}

Sampel penelitian ini hanya pada karyawan Bank Rakyat Indonesia Kantor Cabang Bandar Lampung. Karena keterbatasan waktu, kelompok penulis hanya melibatkan lingkup ruang kecil lingkungan Bank Rakyat Indonesia di kota Bandar Lampung dikarenakan penelitian dilakukan pada masa pandemi Covid-19 sebagai akibatnya pada waktu penyerahan kuisioner hanya dibatasi untuk para karyawan yang berada pada Bank.

\section{Ucapan terima kasih}

Puji serta syukur kami ucapkan kehadirat Tuhan Yang Maha Esa sebab atas rahmat serta karunia- nya yang mana sudah membagikan kami seluruh kemudahan dan kelancaran dalam proses penyelesaian riset ini. Secara tulus kami pula mengucapkan terimakasih kepada Profesor. Einde Evana sebagai penguji. Serta terima kasih kepada para dosen- dosen pembimbing yang telah banyak menolong serta sudah berkontribusi banyak sejak mula pengerjaan Riset ini. Serta kepada seluruh rekan kami yang sudah terlibat dalam penyusunan jurnal kami. Walaupun hasil penyusunan riset kami ini masih jauh dari kata sempurna, mudah- mudahan hasil yang didapatkan sebaik kerja keras yang sudah kami berikan guna pembuatan jurnal ini. Sekian dan Terima Kasih. 


\section{Referensi}

Abriani. (1996). Pengaruh Partisipasi dalam Penyusunan Anggaran Terhadap Kepuasan Kerja dan Kinerja Manajer : Role Ambiguity Sebagai Variabel Antara. Tesis. Universitas Gadjah Mada.

Abriani. (1996). Pengaruh Partisipasi dalam Penyusunan Anggaran Terhadap Kepuasan Kerja dan Kinerja Manajer : Role Ambiguity Sebagai Variabel Antara. Tesis. Universitas Gadjah Mada : Yogyakarta.

Adelin, G. M., Kiagus, A., \& Niken, K. (2021). Pengaruh Partisipasi Anggaran, Kompensasi Finansian dan Kompensasi Nonfinansial Terhadap Kinerja Karyawan PT. Budi Berlian di Lampung. Jurnal Studi Pemerintahan dan Akuntabilitas , 55-67.

Anthony, R. N., \& Govindarajan, V. (2005). Sistem Pengendalian Manajemen. . Jakarta:Salemba Empat.

Ardiansah. (2003). "Pengaruh Kepuasan Kerja dan Komitmen Organisasi terhadap Keinginan Berpindah Kerja Auditor (Studi Kasus pada KAP di Jawa Tengah )”. EKOBIS, 4(2), 141 - 152.

Arikanto. (2010). Prosedur Penelitian, Suatu Pendekatan Praktik. Jakarta: Rineka Cipta.

Bonner, S., \& Pennington, N. (1991). Cognitive Processes and Knowledge as Determinants Of Auditor Expertise. Journal Of Accounting Literature, 10, 1-50.

Burney, L., Henle, C., \& Widener, S. (2009). A Path Model Examining The Relations among Strategic Performance Measurement System Characteristics, Organizationa 1Justice, and Extra- and In-Role Performance. Accounting, OrganizationsandSociety, 34(3-4), 305-321.

Chenhall, R. (2004). The Roleof Cognitive and Affective Conflict in Early Implementation of Activity Based Cost Management. BehavioralResearch in Accounting, 16 .

George, \& Jones. (2005). Understanding and Managing Organizational Behavior 4th Edition. Pearson Prentice Hall.

Ghozali, \& Imam. (2011). Structural Equation Modeling Metode Alternatif Dengan Partial Least Square (PLS) Edisi 3. Semarang: Badan Penerbit Universitas Diponegoro.

Hameed, A., \& Waheed, A. (2011). Employee development and itsaffecton employee performance a conceptual framework. International journal of business and socials science, 2(13), 224-230.

Handoko, T., \& Hani. (2014). Manajemen Personalia dan Sumber Daya Manusia Edisi 2 . Yogyakarta: BPFE.

Hansen, \& Mowen. (2009). Akuntansi Manajemen, Edisi 8. Jakarta: Penerbit Salemba Empat.

Hansen, Don, R., Marryane, M., \& Women. (2004). Akuntansi Manajemen, Edisi tujuh. Jakarta: Salemba Empat.

Harsuko, \& Riniwati. (2011). Mendongkrak Motivasi dan Kinerja: Pendekatan Pemberdayaan SDM. Malang: UB Press.

Hartono, \& Jogiyanto. (2015). Metode Penelitian Bisnis: Salah kaprah dan pengalaman-pengalaman. Edisi 6. Yogyakarta Indonesia: BPFE UGM.

Hofstede, e. (1990). Measuring Organizational Cilture: A Qualitatitive and Quantitative Study Across Twenty Cases Administrative Science Quarterly, 35, 286-316.

Hoque, Zahirul, \& Brosnan, P. (2007). Alligning Industrial Relatoins Risk, Budgetary Partcipation, and Budgating Measures of Performance: Impact on Managerial Performance. SSRN .

Ikhsan. (2005). Akuntansi Keperilakuan. Jakarta : Salemba Empat.

Kreitner, \& Kinicki. (2001). Organizational Behavior. New York: McGraw-Hill Companies, Inc.

Kusuma. (2003). Topik Penelitian Akuntansi Keperilakuan dalam Jurnal Behavioral Research In Accounting (BRIA). Jurnal Bisnis dan Akuntansi, 5(2), 147-166.

Lawler. (2003). Empowering Service Employees. Sloan Management Review 36 (Summer), 73-84.

Listianto, Tony, \& Bambang, S. (2007). Pengaruh Motivasi, Kepuasan, Dan Disiplin Kerja Terhadap Kinerja Karyawan (Studi Kasus di Lingkungan Pegawai Kantor PDAM Kota Surakarta).

Locke. (1976). The nature and causes of job satisfaction. In Handbook Of Industrial and Organizational Psychology. Chicago: Ran McNally. 
Mah'd, Osama, \& Khadash. (2013). The Impact of Budgetary Participatio $\mathrm{n}$ on Managerial Performance: Evidence from Jordanian University Executives. Journal ofApplied Finance \&Banking, 3(3), 133-156.

Marsden. (1996). An Exploration Of the Spoused Organizational Culture Of Public Accounting Firms. Accounting Horison. September. American Accounting Association. 10 (3) , 26-53.

Mehamba. (2014). Pengaruh Kompensasi, Kepuasan Kerja dan Motivasi Kerja terhadap Kinerja Karyawan.

Milani, K. (1975). The Relationship of Participation in Budget-Setting to Industria Supervisor Performance and Attitudes : A Field Study. The Accounting Review, 50 .

Nafarin, M. (2004). Penganggaran Perusahaan. Jakarta: Penerbit Salemba Empat.

Prayoga, L. B., \& Zulvia, K. (2021). The Influence of Organizational Culture and Working Environment on Employee Performance at PT. Pusaka Ayu Bahari. Reviu Akuntansi, Manajemen, dan Bisnis (Rambis), 21-26.

Putri, Z., Yuliansyah, \& Pigo, N. (2021). Pengaruh Akuntabiltas dan Budaya Organisasi Terhadap Kinerja Organisasi pada Rumah Sakit Swasta Kota Bandar Lampung. Jurnal Studi Pemerintahan dan Akuntabilitas, 43-54.

Robbins, \& Judge. (2015). Perilaku Organisasi Edisi 16. Jakarta: Salemba Empat.

Robbins, \& P, S. (2003). Perilaku Organisasi, Jilid 2. Jakarta: PT. Indeks Kelompok Gramedia.

Robbins, \& Stephen, P. (1997). OrganizationalBehavior. New York: Prentice-Hall Company.

Robbins, S. (2008). Perilaku Organisasi. Edisi Bahasa Indonesia. Jakarta: PT INDEKS Kelompok GRAMEDIA.

Sholihin, M., \& Pike, R. (2010). Organizational Commitment in The Police Service: Exploring The Effects of Performances Measures, Procedural Justice, and Interpersonal Trust. Financial Accountability and Management, 26 (4), 392-413.

Sugiyono. (2003). Metodologi Penelitian Administrasi. Bandung: Alfabeta.

Undang-Undang Nomor 10 Tahun 1998 tentang Perbankan.

Urbach, N., \& Ahlemann, F. (2010). Structural Equation Modeling in Information Systems Research Using Partial Least Square. Journal of Information Technology Theory and Application. 11(2), 539.

Verawati. (2009). Pengaruh Komitmen Organisasi, Partisipasi dan Motivasi Terhadap Kinerja Karyawan Pada PT Bank Lippo Tbk Cabang Kudus. ISSN : 1411-1799.

Yahya, Nor, M., Nik Ahmad, N. N., \& Fatima, A. (2008). Budgetary Participation and Performance: some Malaysian Evidence. International Journal of Public Sector Management, 21(6),, 658-673. 